\title{
PRESENCE OF SCANDINAVIAN DESIGN ELEMENTS IN CHAIR MANUFACTURING IN MACEDONIA
}

\author{
Petar Namicev, ${ }^{1}$ Emilija Shopova ${ }^{2}$ \\ ${ }^{1,2}$ University Goce Delcev Shtip, Republic of Macedonia \\ petar.namicev@ugd.edu.mk, emeshopova@gmail.com
}

\section{Original Scientific Paper doi:10.5937/jouproman6-17223}

\begin{abstract}
Scandinavian design as a style, within the filed of furniture history and interior, emerges and develops in the aftermath of World War II in Central Europe, to be retained later in the Nordic countries: Sweden, Denmark and Norway. The Scandinavian modern style is mainly characterized by wood furniture with bright shades, pronounced lines, forms and shape. As one of the most popular leading domestic styles of today, the emphasis is placed on the design of furniture and interior, specifically the design of unique, simple and recognizable chairs.
\end{abstract}

The concept and analysis of the research material refers to the presence of the Scandinavian design within the production of chairs in Macedonia, i.e. its influence, the chronology of development, characteristics of similar elements of design and production technology. The application of the basic elements to domestic production begins to gradually increase in the mid-1990s and achieve a high degree of representation of the characteristics of this style and at the same time the highest current market demand. Based on the carried out analyzes, Scandinavian style is present in the overall production of chairs in Macedonia, including inspiration and design, ergonomics, production stages and materials.

Key words: Chair, design, construction, constituent elements, production stages, materials

\section{Introduction:}

The Scandinavian design as an artistic direction is guided by the basic principles of Modernism - achieving the optimal balance between form, function, material, color, texture, endurance and price, which will result in practical design solutions (Wilkins, Schultz, Linda, 2009). The Scandinavian furniture is mainly based on the techniques of bending the wood, as well as the production of wooden and iron frames for upholstered furniture. And basically it consists of a twisted wood/ lumber and a tubular metal construction, which is eminently suitable for high-volume industrial production (Raicheva, 1999). A typical Scandinavian chair is a mix of flat lines with slightly rounded details. More specifically, the backrests and the seat of the chairs are rarely at right angles (Nelson and Taylor, 2012).

The production of furniture (chairs) in Macedonia has tradition and experience for more than fifty years. More precisely, the factories in Eastern Macedonia have a completely rounded technological process of producing chairs, i.e. they specialize in the production of curved elements of beech wood, high-quality fabrics and exclusive processing. The scope of the Scandinavian design elements, which are related to the design and the way of production, changed and increased at different times, depending on the interest of the market. Starting with the simplest basic, features (basic material - the wood), further by simplifying the models and constituent elements, to finally reach up to today's perfected designs with a high percentage of representation of the Scandinavian elements. 


\section{Correlation of the domestic} production of chairs from the aspect of the Scandinavian design

Practicality, simplicity and functionality, as the dominant characteristics of the Scandinavian chairs, are also present on the design of chairs in Macedonia, as a kind of a correlation with the concept of world trends for simplifying and practical use of the pieces of furniture.

The Scandinavian chair is characterized by a construction of wooden or (rarely) iron frames, a laminated beech frame with separately shaped teak chipboard for the seat and rear elements. More often, it consists of modular components, rather than an individual onetime product that is easily mounting/ disassembling (Fiell, 2014). In terms of materials, extremely natural materials are used, starting from the light-colored wood for construction, to the choice of the upholstery material. One of the most important features of these chairs is the use of as few materials as possible, based on their history of the organic selection of raw materials.

The similarities are mostly expressed in the design and production of a chair, for which it is necessary to define the level of representation in the domestic production, in relation to the stylistic elements, through the comparative analysis.

\subsection{Beginning of the application of elements}

In the mid-nineties, the application of the basic characteristics of the Scandinavian elements to the production of chairs in Macedonia began. The application is based on the use of beech wood as primary material, simple models of stools and exceptional wooden construction, without the use of upholstery.

Among the first beginnings of the use of Scandinavian elements on domestic production was recorded at the Factory in Kochani Istra with an area of $70,000 \mathrm{~m}^{2}$ and about $11,000 \mathrm{~m}^{2}$ of plants). With a tradition and experience of more than 50 years, it is one of the leading factories with domestic production of chairs. The factory Mebel Inzenering - Shtip is one of the most sought manufacturers of high quality wooden chairs in Eastern Macedonia and wider. Among these domestic manufacturers of chairs, there is a high demand for innovative and unique chairs in the factory Jumis-Kochani, which is newer in the production of this type of chairs.

\begin{tabular}{|c|c|c|c|}
\hline Time period & $\begin{array}{l}\text { Beginning of the } \\
\text { application of } \\
\text { elements }\end{array}$ & Demand & Materials \\
\hline $\begin{array}{l}\text { - Istra - } 50 \\
\text { years; } \\
\text {-Mebel } \\
\text { Engineering } \\
\text { - 25 years; } \\
\text {-Jumis - } 18 \\
\text { years old; }\end{array}$ & $\begin{array}{l}\text {-wooden legs; } \\
\text {-easy upholstered } \\
\text { seats; } \\
\text {-decorated chairs } \\
\text { with or without } \\
\text { upholstery; } \\
\text {-closed elements in } \\
\text { the part of the } \\
\text { backrest; }\end{array}$ & $\begin{array}{l}\text {-interest in the } \\
\text { market; } \\
\text { - world trends; } \\
\text {-use of simple } \\
\text { and functional } \\
\text { furniture; }\end{array}$ & $\begin{array}{l}\text {-lumber, beech, } \\
\text { ash tree; } \\
\text {-plywood -for seat } \\
\text {-leather,eco- } \\
\text { leather, sponge, } \\
\text { furniture fabric- } \\
\text { for upholstery }\end{array}$ \\
\hline
\end{tabular}

Table 1. Parameters on several basic features of the chairs in the examined factories 
This period of 18 to 50 years of analysis of the use of elements in domestic companies speaks of the production, where a significant influence in its development from the models and elements of the production of the Scandinavian design existed. The impact of this style has been stretching over the years, with increased interest in the market and consumer demand for simplified and functional furniture. The increased application is in correlation with a higher degree of representation of certain elements of the style in the Macedonian production.

\subsection{Stages of the production process}

The process of chair production is a complex process, composed of separate phases, in which the preparation, construction and processing of the material are carried out (Gruevski and Simakoski, 2003). The factories have a complete rounded technological process of producing chairs, where a mutual influence between all stages of production can be seen. Starts with a careful selection of trees from strictly controlled forests and continues with the basic construction and processing of raw materials.

\begin{tabular}{|l|l|}
\hline Planning & $\begin{array}{l}\text { - accurately organizing the storehouse; } \\
\text { - reutilizing waste products; } \\
\text { - wisely planning each production phase; }\end{array}$ \\
\hline $\begin{array}{l}\text { Selection of raw } \\
\text { materials }\end{array}$ & $\begin{array}{l}\text {-beech wood - carefully selected in Macedonian forests, } \\
\text { respecting environmental impact and reforestation protocols; }\end{array}$ \\
\hline Logging and drying & $\begin{array}{l}\text {-determining the natural "defects" and their reduction; } \\
\text {-the logs are carried into the mill, where a saw machine cuts them } \\
\text { into pieces with predetermined thickness; } \\
\text {-the cut and trimmed pieces of lumber are moved to an area to be } \\
\text { dried; }\end{array}$ \\
\hline Shaping elements & $\begin{array}{l}\text {-shape, model and cut product parts from the previous made } \\
\text { lumbers; }\end{array}$ \\
\hline Creating the frames & $\begin{array}{l}\text {-the parts that make up the back or the front part of the frame are } \\
\text { assembled in this phase; } \\
\text {-the use of the correct amount of glue is particularly important; }\end{array}$ \\
\hline Give some color & $\begin{array}{l}\text {-spraying the frames - the frames are sprayed with electric paint } \\
\text { gun which produce an even coat of paint; }\end{array}$ \\
\hline $\begin{array}{l}\text { Stitching, cutting and } \\
\text { upholstering }\end{array}$ & $\begin{array}{l}\text {-in this phase the frame is padded and upholstered. Webbing and } \\
\text { springs are skillfully fixed by hand to guarantee the best } \\
\text { resistance of the seats; }\end{array}$ \\
\hline Quality check & - cohesion to the company`s distinctive quality standards; \\
\hline
\end{tabular}

Table 2. Description of the stages of the production process

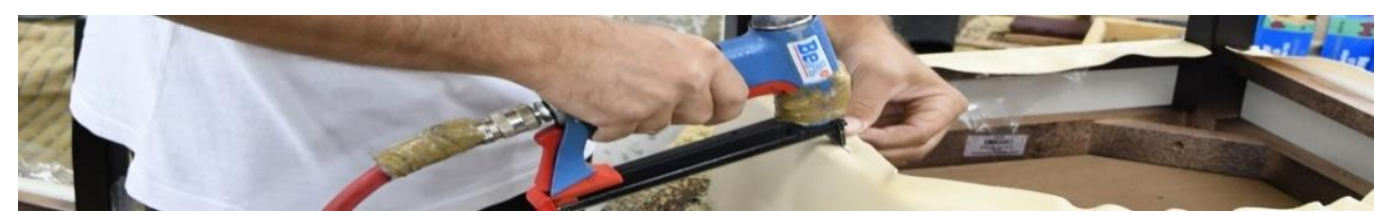

Figure.1Illustrations from separate phases in the process of construction and processing of chairs 
The production process of the chair includes several key stages: the preparation of the raw material, the construction of the material and its final processing. These three basic phases are complemented by several additional stages, in order to distribute the overall process of multiple sub processes, in separate plants, for simpler and more accurate performance of the work.

\subsection{Construction and processing} of the constituent elements
The technological preparation in the industrial production of a chair, consists of several stages, connected in one continuous process, where in separate specialized plants serial elements of the chair are made (Grbac and Ivelic, 2014). Each procedure is performed separately, but there is a mutual correlation and connection between the separate stages of production of the concrete elements in the process. The process is divided into: construction of frames/construction, seat, legs, backrests and armrests.

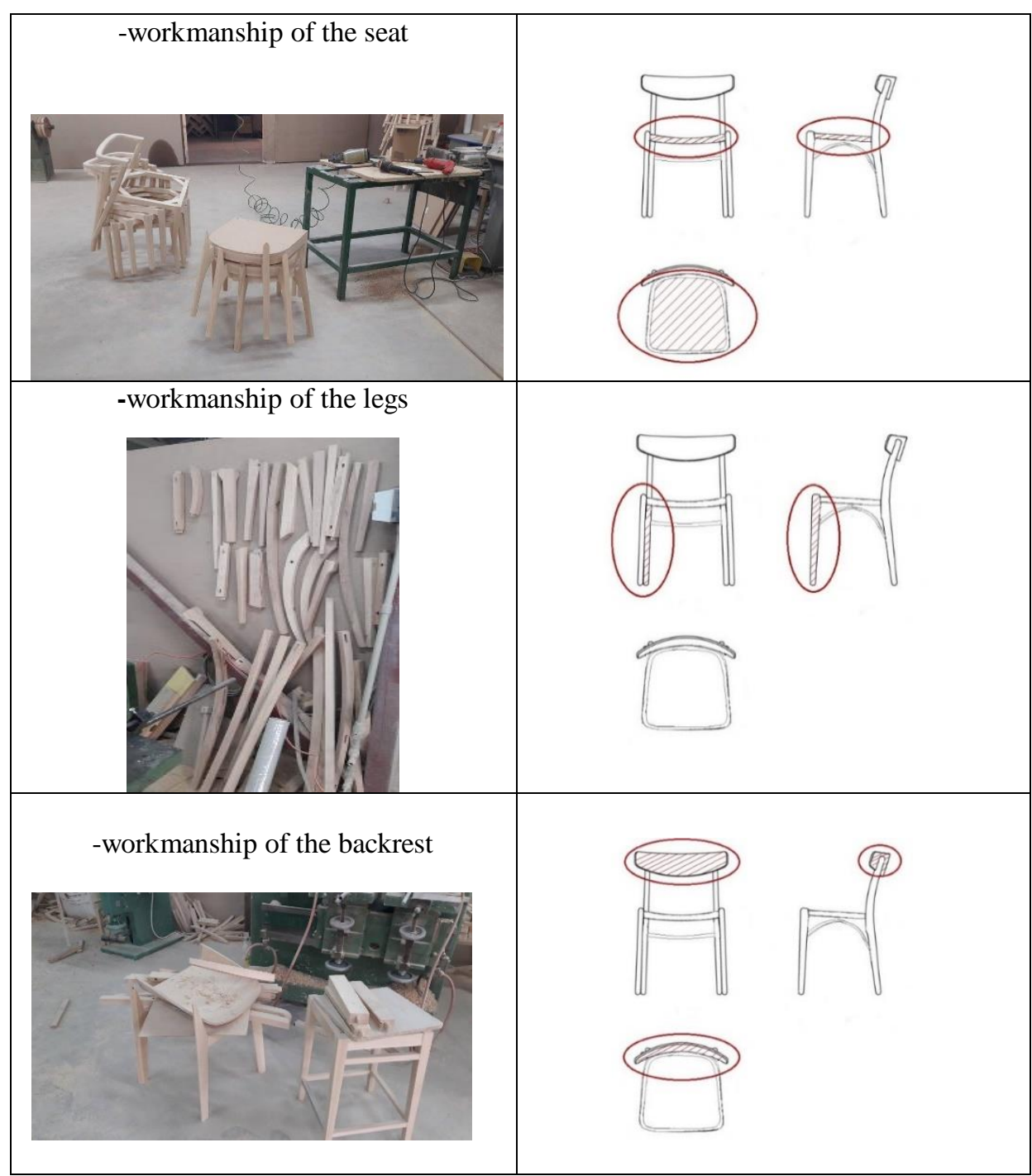




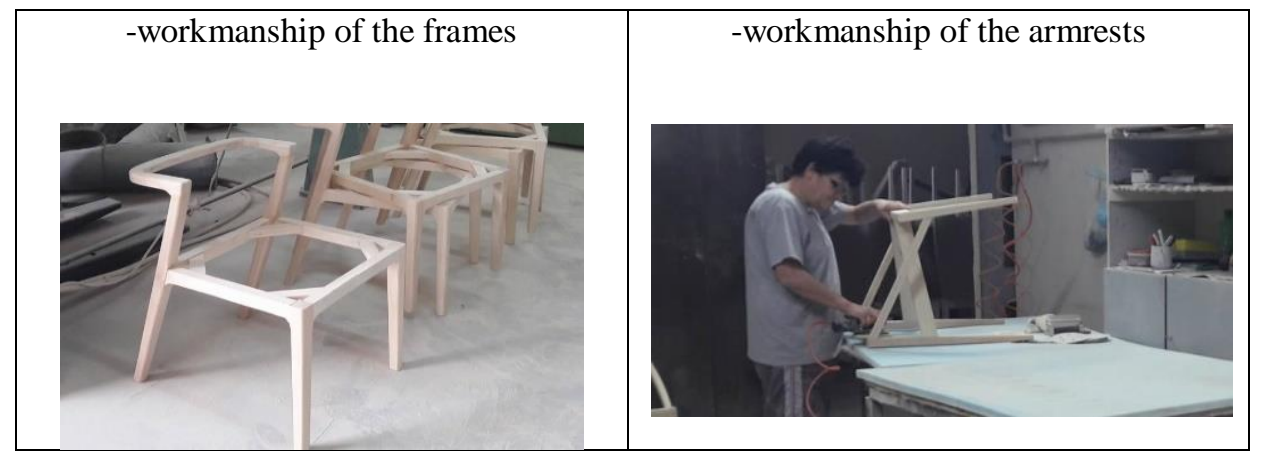

Table 3. Illustrations from the processes of making the components of the chair: seat, legs and backrest

The domestic production of chairs involves the use of light wood-beech as a basic material for making the structure / frames of the chairs. Frames are exclusively wood. The construction is a blend of flat lines with varying degree of curvature of individual elements. The wrapping of the wood is done on plywood, through high-frequency generators operating under high voltage, using patterns of solid wood or metal, and the gluing is made with electricity. For the fabrication of the frames beech wood is used, plywood (laminated) from beech, while the seat is made of chipboard. Most often, the natural color of the wood is retained, but if the client desires, they are painted in color. And the painting is done with water colors also known as baits.

The joining of the elements is carried out most often with glue, screws and connections. The most common type of connection is the so-called pellet - a kind of dent, built into the wood itself: a protruding cylindrical part for entry into the opening on the other side. Regarding the constituent elements, this is usually the case for individual products, where all the constituent elements are joined, in contrast to the Scandinavian chairs, where most often modular components are easily mounted and dismantled. 


\begin{tabular}{|c|c|c|}
\hline \multicolumn{2}{|r|}{ Scandinavian chairs } & Domestic production \\
\hline \multirow{9}{*}{$\begin{array}{l}\text { Method } \\
\text { of } \\
\text { constructi } \\
\text { on: }\end{array}$} & - technique of wood bending & $\begin{array}{l}\text { bending is performed on plywood, through high- } \\
\text { frequency generators operating under high voltage, using } \\
\text { patterns of solid wood and metal, and gluing is with } \\
\text { electricity }\end{array}$ \\
\hline & -wooden and iron frames & only wooden frames - construction \\
\hline & $\begin{array}{c}\text { - a mix of flat lines with slightly rounded } \\
\text { detail }\end{array}$ & $\begin{array}{l}\text { a mix of flat lines with different degree of roundness of } \\
\text { individual elements }\end{array}$ \\
\hline & $\begin{array}{c}\text { - teak wood and laminated beech frame } \\
\text { with specially shaped teak plywood for } \\
\text { the seat and rear elements }\end{array}$ & $\begin{array}{l}\text { beech, plywood (laminated) from beech and chipboard } \\
\text { for the seat }\end{array}$ \\
\hline & $\begin{array}{c}\text { - modular components, rather than an } \\
\text { individual one-time product }\end{array}$ & $\begin{array}{l}\text { individual products, the elements are merged by means of } \\
\text { screws, glue or connections }\end{array}$ \\
\hline & - easily mounting / dismantling chairs & dismantling - can not be folded / folded \\
\hline & - dimensions & the dimensions will be shown graphically \\
\hline & - period of preparation & $\begin{array}{l}\text { the elements are produced serially, for a larger number of } \\
\text { chairs, only the drying of the lumber is about 2-3 months }\end{array}$ \\
\hline & - merging elements & $\begin{array}{c}\text { usually with glue, screws and bonding called Kulak- a kind } \\
\text { of dump built into the wood itself: a cylindrical section for } \\
\text { entry into the opening on the other side }\end{array}$ \\
\hline \multirow[t]{2}{*}{ Legs } & $\begin{array}{l}\text { - merging legs-directly attached to the } \\
\text { bottom of the seat }\end{array}$ & are usually directly attached to the bottom of the seat \\
\hline & - type of connection & usually the fusion - Kulak - a kind of dump or screws \\
\hline \multirow{5}{*}{ Seat } & - seat of plywood & plywood when it should be upholstered \\
\hline & - backrest and seat, rarely under right & it has both a right angle and no right angle \\
\hline & $\begin{array}{l}\text { - possibility to remove the seat from its } \\
\text { frame }\end{array}$ & $\begin{array}{l}\text { here is a possibility of extraction, by screwing the } \\
\text { necessary screws }\end{array}$ \\
\hline & -upholstery - latex foam and & sponge, eraser and it is upholstered on the spring, foam, \\
\hline & - woven hemp seat & not used \\
\hline \multirow{2}{*}{ Armrests } & -mostly without armrests, to save space & with or without armrests \\
\hline & - laminated curved wooden frames & laminated and wooden, most often from plywood \\
\hline \multirow{2}{*}{ Backrest } & - mostly plywood / wood rather than & very rare upholstery, usually only wood \\
\hline & - rarely is it at right angles & is usually not a strictly right angle \\
\hline
\end{tabular}




\begin{tabular}{|c|c|c|}
\hline \multicolumn{2}{|r|}{ Scandinavian chairs: } & Domestic production: \\
\hline \multirow{9}{*}{ Materials } & $\begin{array}{c}\text { - light-colored wood: teak wood, oak, pine, } \\
\text { beech, birch }\end{array}$ & $\begin{array}{c}\text { also light - the light of the beech depends on how you cut } \\
\text { it - inwards - the marrow is reddened }\end{array}$ \\
\hline & $\begin{array}{c}\text { - experimenting with plastics -technique of } \\
\text { sintering and with steel }\end{array}$ & no use of plastic \\
\hline & - use as few materials as possible & usually only beech \\
\hline & - from where they are imported & from Macedonia - Macedonian Forests \\
\hline & $\begin{array}{c}\text { - treating the materials - with special oils to } \\
\text { reduce the yellow tones of the tree }\end{array}$ & $\begin{array}{l}\text { no such oils are used, because they are not } \\
\text { environmentally friendly }\end{array}$ \\
\hline & $\begin{array}{l}\text { retaining the natural color and detail of the } \\
\text { tree }\end{array}$ & $\begin{array}{l}\text { most often the natural color is retained, but at the } \\
\text { customer's request, it is a color paint. Painting is done } \\
\text { with water colors - the so-called - baits }\end{array}$ \\
\hline & - which colors dominate? & $\begin{array}{l}\text { at the customer's request, but most often white, beige, } \\
\text { natural wood, yellow, green. }\end{array}$ \\
\hline & $\begin{array}{l}\text {-upholstery: linen, cotton, hemp, jute, } \\
\text { wool, leather, fur }\end{array}$ & ther, furniture fabrics, sponge, eraser, the spring is tucked \\
\hline & -fabrics and motifs from nature & there are different motives \\
\hline \multirow[t]{2}{*}{ Inspiration } & - ergonomic inspiration & $\begin{array}{c}\text { The ergonomic dimensions are certainly observed } \\
\text { according to the regulations, but the design of a chair is } \\
\text { most often determined by the buyer, according to a } \\
\text { particular model }\end{array}$ \\
\hline & $\begin{array}{l}\text { - interpretation of prominent historical } \\
\text { forms, vintage furniture-antique }\end{array}$ & $\begin{array}{l}\text { there is an interruption of historical models, through the } \\
\text { application of some ancient colors, effects of old age, etc. }\end{array}$ \\
\hline
\end{tabular}

Table.4. Similarities and differences in features betweendomestic and Scandinavian chairs

In terms of armrests, they are made in two variants: with and without backrests, but the simple ones without backrests are increasingly required. The material for production is laminated and wooden backrests, most often of plywood. The materials that are used to make the upholstered part of the models are: leather, furnishing fabric, sponge, elastic band and are taped on the spring, foam and the like.

The interpretation of antiquity and the use of vintage furniture in the Scandinavian interior, as one of the more important features of the style, are applied in the Macedonian production of chairs too. In the Istra factory, there is a design of traditional wooden chairs, where the wood itself and the application of some ancient colors achieve the so-called effect of old age - inspiration from antiquity.

Through a detailed comparative analysis of the method of construction, including the concrete development of the individual components of the home chairs, through their basic characteristics, we can conclude that there is a high degree of similarities, and at the same time representation of the elements of the Scandinavian design on our domestic production. The large volume of similarities is based primarily on: lightcolored wood as a basic material, a technique of bending the wood, simplifying the constituent elements and using as few materials as possible.

\subsection{Ergonomic Conception}

The technical analysis is based on the comparison of the dimension of a specific Scandinavian chair - Chair CH36 Hans J Wagner (Holmsted Olesen, 2014) with the dimensions of a domestic chair with a similar design. 

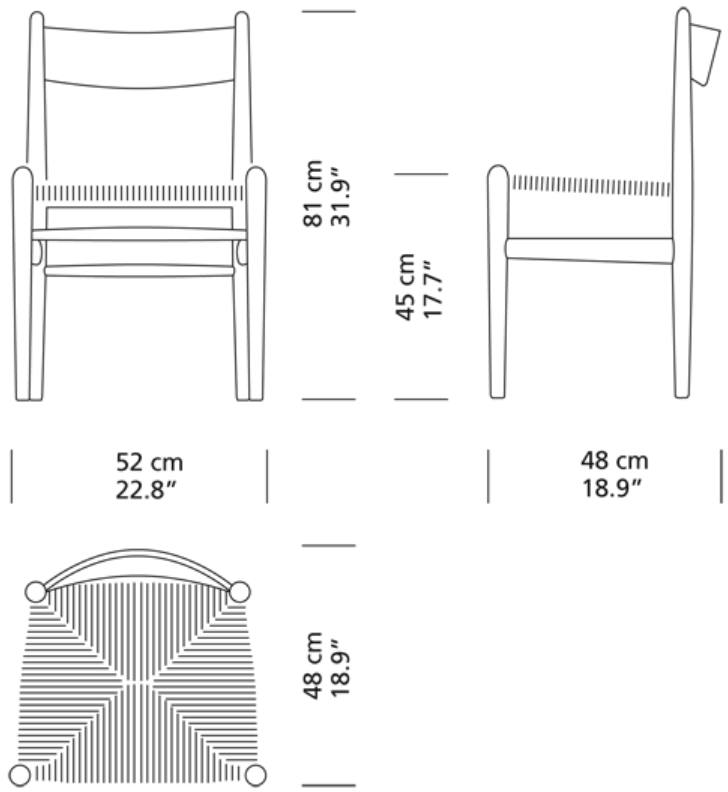

$48 \mathrm{~cm}$

$18.9^{\prime \prime}$

Figure.3

Technical drawing 1. Chair CH36 - Hans J Wagner
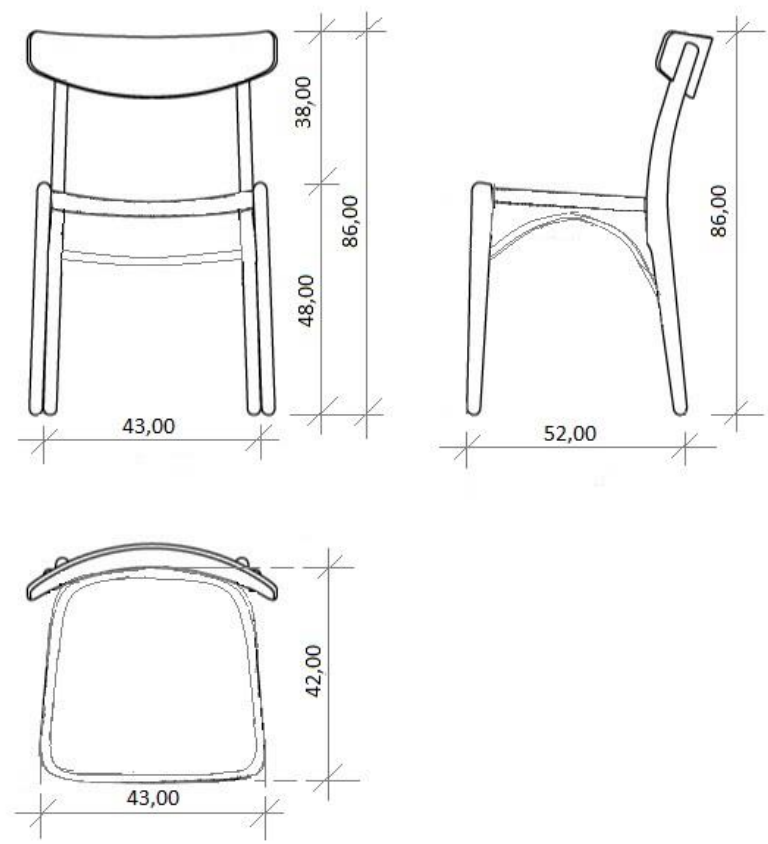

Figure.4

Technical drawing 2.Chair - B-222-D - Istra Kochani

\begin{tabular}{|c|c|c|}
\hline Dimension type: & Scandinavian chair: & Domestic chair: \\
\hline Height of the chair D & $81 \mathrm{~cm}$ & $46 \mathrm{~cm}$ \\
\hline Height of the seat SH & $45 \mathrm{~cm}$ & $42 \mathrm{~cm}$ \\
\hline Depth of the seat SD & $48 \mathrm{~cm}$ & $43 \mathrm{~cm}$ \\
\hline Seat width SW & $48 / 52 \mathrm{~cm}$ & $52 \mathrm{~cm}$ \\
\hline Chair width D & $48 \mathrm{~cm}$ & $\mathrm{~cm}$ \\
\hline
\end{tabular}

Table 5. Comparison between the dimensions of the two chairs 
The comparison is based on the technical drawings of the two chairs, which show the three views of the chair. Dimensions of the domestic chair (Panero and Zelnik, 1986) were obtained on the basis of the generalization of three specific chairs.

On the basis of the performed comparative analysis can be noted that the difference is small, for only $4-5 \mathrm{~cm}$. What is interesting is that in relation to the height and width of the chairs, as the main indicators, the domestic chair is slightly larger than the Scandinavian, while the seat is slightly larger at the Scandinavian chair.

\subsection{Statistical analysis}

Analysis of the presence of the Scandinavian characteristics in the chairs at the level of the investigated factories in order to draw concrete conclusions about the influence and degree of the representation of the Scandinavian characteristics on the domestic production of chairs of that type.

\begin{tabular}{|c|c|c|c|}
\hline Type of feature: & $\begin{array}{c}\text { Jumis } \\
\text { Kochani }\end{array}$ & $\begin{array}{c}\text { Istra } \\
\text { Kochani }\end{array}$ & $\begin{array}{c}\text { Mebel } \\
\text { Engineering }\end{array}$ \\
\hline Technique of wood bending & $50 \%$ & $85-90 \%$ & $90 \%$ \\
\hline $\begin{array}{c}\text { In which part is the most } \\
\text { pronounced curved shape }\end{array}$ & backrest & $\begin{array}{c}\text { backrest, } \\
\text { armrests, } \\
\text { back legs }\end{array}$ & $\begin{array}{c}\text { backrest, } \\
\text { armrests and } \\
\text { seat }\end{array}$ \\
\hline Wooden frames & $\begin{array}{c}\text { Wood and } \\
\text { metal }\end{array}$ & $100 \%$ & $90 \%$ \\
\hline Beech - light wood & $\begin{array}{c}\text { Beech and } \\
\text { clear }\end{array}$ & $100 \%$ & $100 \%$ \\
\hline Seat of plywood & $80 \%$ & $40 \%$ & $50 \%$ \\
\hline $\begin{array}{c}\text { Backrest - laminated beech } \\
\text { frame }\end{array}$ & $60 \%$ & $85 \%$ & $90 \%$ \\
\hline Most often without armrests & $65 \%$ & $60 \%$ & $75 \%$ \\
\hline $\begin{array}{c}\text { The legs are directly attached } \\
\text { to the lower part of the seat }\end{array}$ & $85 \%$ & $65 \%$ & $85 \%$ \\
\hline $\begin{array}{c}\text { Preserving the natural color } \\
\text { and detail of the tree }\end{array}$ & $45 \%$ & $40 \%$ & $65 \%$ \\
\hline $\begin{array}{c}\text { Easy mounting / } \\
\text { disassembling }\end{array}$ & $0 \%$ & $0 \%$ & $0 \%$ \\
\hline Woven hemp seat & $10 \%$ & $0 \%$ & $0 \%$ \\
\hline $\begin{array}{c}\text { Experimenting with plastic } \\
\text { Seat upholstery; }\end{array}$ & $0 \%$ & $0 \%$ & $0 \%$ \\
\hline
\end{tabular}

Table 7.Percentage representation of the Scandinavian characteristics in the total production of chairs in each factory separately ${ }^{1}$

\footnotetext{
${ }^{1}$ The data refer to given information from the last month of sale / production
} 
By analyzing the percentage representation of several distinct most common Scandinavian characteristics, the size of production and the percentage of demand, in each factory separately (through several separated chairs), several conclusions can be drawn for generalization of the impact and the degree of representation of the Scandinavian design on the domestic production of chairs.

Based on the analysis of the representation of the Scandinavian characteristics in the chairs at the factory level, according to the data in Table no.7, it can be generalized that the factory IstraKochani and the factory Mebel Engineering in Shtip have an approximately similar percentage of Scandinavian characteristics, unlike the factory Jumis Kochani, where smaller percentage of the representation of the characteristics is evident. From the same analysis, we can also see that the characteristics: the techniqueof bending the wood, the light colored wood - beech as the basic material and the wooden frames, are represented equally with the highest percentage in the three factories;
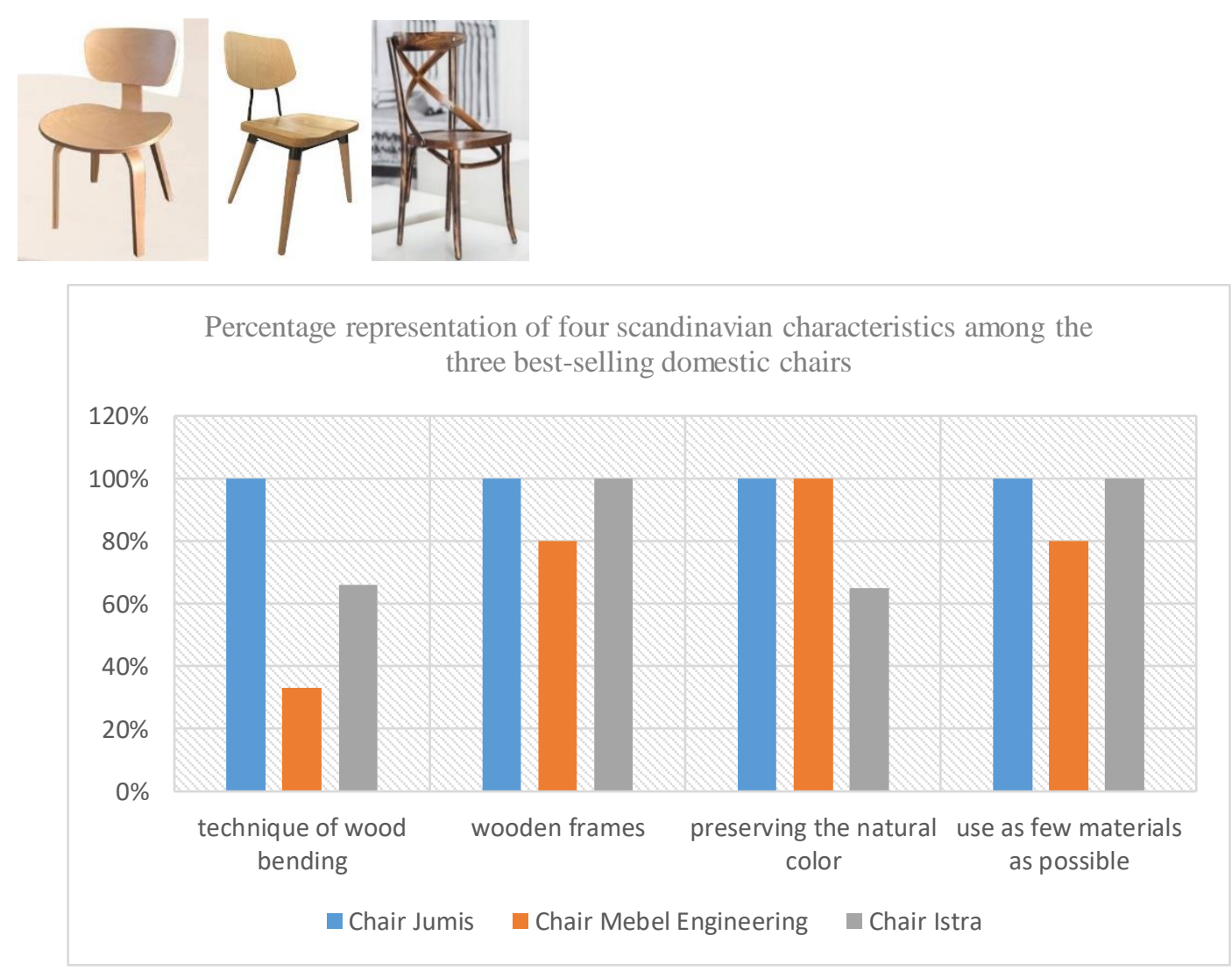

Chart 1. Percentage representation of the Scandinavian characteristics for the chairs of each factory, with the greatest demand / production

According to the graphic presentation of the three most requested chairs in the three factories, in terms of the percentage representation of four Scandinavian characteristics, we can conclude that the chair of the factory
Mebel Engineering-Shtip is with the lowest percentage of representation of the specific characteristics, while the stool of the factory Jumis in Kochani is with the highest percentage of representation of the specific characteristics; 


\section{Conclusion}

The Scandinavian furniture, designed by Scandinavian designers such as Arno Jacobsen, Hans Wegner, Panton and Alvar Alto, after itsinternational presentation, was widely used and elements in the industrial furniture production are used (Fiell, 2014), to this day. With its recognizable rounded and organic shapes combined with minimalist, multifunctional furniture, it is a recognizable reflection of convenience, simplicity and uniqueness. The Scandinavian chair, as the most expressive piece of furniture of this style, is characterized by a combination of flat lines with different degree of curvature of individual elements, light-colored wood and extremely natural materials for upholstered elements.

Practicality, simplicity and functionality, as the dominant features of the Scandinavian chairs, are widespread in the concept of today's home interior. This Nordic style is also present in the design of chairs in Macedonia, as a kind of correlation with the concept of the world trends for simplifying and practical use of the pieces of furniture.

Pursuant to the numerous analyzes and studies of the domestic production of chairs of this type, including design, ergonomics, construction, production stages and materials, the following can be generalized:

- The three most common Scandinavian features in the production of chairs in Macedonia are: the bending of the tree, the basic material - light-colored wood - beech and wooden frames;

- The largest percentage of representation of the Scandinavian characteristics, from the examined factories for production of chairs in Eastern Macedonia, are the factories Mebel Engineering Shtip and the factory Istra Kochani;

- The most demanding models of chairs, according to the data from the last month of sale and production, in all of the three factories, have a high percent - (65\%-100\%) of representation of the scandinavian cgaracteristics;

Based on the conclusions, we can ascertain a dominant influence of the Scandinavian design in the overall development of industrial production in Macedonia. According to the statistical analysis, the influence and dominance of the Scandinavian design is present in the entire technological process, from the choice of materials and the industrial mode of production to the design of patterns and the presence of global trends in the domestic production.

\section{References:}

1. Wilkins, D., Schulz, B., i Lindaf, K. (2009). Umetnost minata, umetnost segashna, Skopje, Nampres.

2. Fiell, Ch. \& Fiell, P. (2012). Design of the 20th Century, Cologne, Taschen.

3. Fiell, Ch. \& Fiell, P. (2014). Scandinavian Design, Cologne, Taschen.

4. Grbac, I. i Ivelic, Z. (2014). ). Ojastuceni namjestaj, Zagreb, Šumarski Fakultet.

5. Gruevski, T. i Simakoski, N. (2002). Elementi na drvenite konstrukcii, Skopje, UKIM-SFS.

6. Gruevski, T. i Simakoski, N. (2003). Konstruiranje na mebel, Skopje, UKIM-SFS

7. Holmsted, O. C. (2014). Wagner - Just one good chair, Berlin, Hatje Cantz.

8. Nojfert, E. (2009). Arhitektonsko proektiranje, Skopje, Ars Lamina.

9. Nelson, K. i Taylor, D. (2012). Enterieri Voved, Skopje, Ars Lamina.

10. Raycheva, R. (1999). Istorija na interiora $i$ mebelite, Sofia, Lesnotehniceski Univerzitet.11. Panero, J. i Zelnik, M. (1986). Antropometrijske mere $i$ enterier, Beograd, Gradjevinska knjiga. 
(JPMNT) Journal of Process Management - New Technologies, International Vol. 6, No.1, 2018. 